\title{
Analisis Pengaruh Pendidikan Keluarga dan Lingkungan Sosial Terbentuknya Identitas LGBT
}

\author{
Parsaoran Barutu, ${ }^{1}$ Alvyn Cesarianto Hendriks, Stimson Hutagalung, \\ Rolyana Ferinia \\ Program Magister Filsafat Universitas Advent Indonesia1, 2, 3, 4 \\ pdt.parsaoran@yahoo.com ${ }^{1}$
}

\begin{abstract}
LGBT identity becomes a problem and conflict in religion and even for norms in the culture of society in general. But not a few also support the existence of LGBT that this identity is a normal and natural thing. From the perspective of religion and society that rejects the LGBT identity, the researcher intends to provide early prevention of the emergence of LGBT identities that are considered incorrect with the aim of avoiding and reducing identities that are considered incorrect so that the nature of this research is not only blaming the existence of LGBT identities but helping families -Families approach children from an early age with the aim of helping them to return to their accepted sex identity based on God's Word by providing family education and a social environment that plays a role in preventing the rise of LGBT sex identities in the social community. This study uses a descriptive qualitative method by conducting in-depth interviews from experts who are determined as informants using a literature study approach. The results of this study indicate that LGBT sexual identity is caused by the lack of carrying out the function of family education and the influence of the social environment that is not good.

Keywords: Family Education, Influential Surrounding Society. LGBT.
\end{abstract}

Abstrak: Identitas LGBT menjadi persoalan dan pertentangan dalam agama dan bahkan bagi norma-norma dalam kebudayaan masyarakat pada umumnya. Namun tidak sedikit juga mendukung keberadaan LGBT bahwa identitas tersebut adalah hal yang normal dan wajar. Dari pandangan agama dan masyarakat yang menolak identitas LGBT tersebut, peneliti bermaksud untuk memberikan pencegahan dini terhadap maraknya timbulnya identitas LGBT yang dianggap tidak benar dengan tujuan akan mengindari dan mengurangi identitas yang dianggap tidak benar sehingga sifat penelitian ini tidak sekadar menyalahkan keberadaan identitas LGBT namun menolong keluarga-keluarga melakukan pendekatan kepada anak-anak sejak dini dengan tujuan membantu mereka untuk kembali kepada identitas seks yang diterima berdasarkan Firman Tuhan dengan memberikan pendidikan keluarga dan lingkungan sosial yang berperan untuk mencegah maraknya identitas seks LGBT ditengah masyarakat sosial. Penelitian ini menggunakan metode kualiatif yang sifatnya deskriptif dengan melakukan wawancara mendalam dari ahli yang ditentukan sebagai informan dengan menggunakan pendekatan studi pustaka. Hasil dari penelitian ini menunjukan bahwa identitas seks LGBT disebabkan kurangnya 
dijalankannya fungsi pendidikan keluarga dan pengaruh lingkungan sosial yang tidak baik.

Kata Kunci: Pendidikan Keluarga, Lingkungan sosial, LGBT

Article History : $\quad$ Received: 15 September 2021 Revised: 26 November 2021 Accepted: 3 Desember 2021

\section{Pendahuluan}

Angka populasi Lesbian, Gay, Bisexual, Transgender (LGBT) di Indonesia semakin besar sekalipun jumlah tersebut tidak dapat dipastikan dari sebenarnya di Indonesia, namun diperkirakan dari tahun ke tahun jumlahnya meningkat sangat signifikan. Pada tahun 2012 Kemenkes memberikan laporannya, ditemukan 1.095.970 penyuka sesama jenis (homoseksual). Dari jumlah tersebut menghidap HIV. ${ }^{1}$ Bahkan di Batam sendiri tahun 2018 jumlah Gay dihitung lewat jumlah anggota disebuah group komunitas gay, didapati jumlah mereka sebanyak 656 orang. $^{2}$

Suryani, anggota DPRD Provinsi Kepulauan Riau menyampaikan temuan yang sangat mengkhawatirkan bahwa diduga jumlah Gay sebagai penyuka sesama jenis pria dengan pria kurang lebih 3 Ribu remaja pelajar di Kota Batam. Jumlah tersebut sebagian besar dibawah usia 18 tahun. Sedangkan untuk Lesbian banyak sekali ditemukan di Kawasan Industri Muka Kuning Batam yang umumnya tinggal di Dormitory yang tersedia. $^{3}$

Dari jumlah yang ada tersebut, kemungkinan besar diantara mereka ada yang berasal dari keluarga Kristen dan mungkin saja diantara mereka ada di organisasi aktif dalam gereja. sementara gereja menolok Identitas Seks LGBT karena bertentangan dengan Alkitab ( Imamat 18:22, 1 Korintus 6:10) Sementara kalangan komunitas LGBT menegaskan bahwa identitas seks mereka dipengaruhi oleh genetik yang meyakinkan diri mereka sendiri bahwa identitas seks mereka tidak salah, namun Tuhan sudah membuatnya demikian dari sejak kelahiran.

${ }^{1}$ Kemenkes, "Kemenkes RI, Estimasi Jumlah Populasi Kunci Terdampak HIV Tahun 2012” (2014).

2Muhammad Ikhsan, "Modus Komunitas LGBT Di Batam Yang Mencengangkan," https://www.batamnews.co.id/berita-39230-modus-komunitas-lgbt-di-batam-yangmencengangkan.html (diakses, 10 Oktober 2020).

${ }^{3}$ Newswire, "Fenomena LGBT: Sekitar 3 Ribu Pelajar Di Batam Diduga Gay" (Batam, February 12, 2016) https://kabar24.bisnis.com/read/20160212/78/518490/fenomena-lgbt-sekitar-3-ribu-pelajar-dibatam-diduga-gay (diakses 31 Agustus 2021). 
Melalui penelitian yang pernah dibuat oleh Munstanski dengan jumlah sampel yang besar, tidak ada bukti yang kuat bahwa seseorang memiliki identitas sex LGBT berasal dari gen. ${ }^{4}$

Jadi sampai sekarang ini tidak ada hasil penelitian yang dapat memberikan bukti adanya hubungan antara genetik dengan orientasi seksual seseorang. Hypothesis Biological theory of LGBT belum dapat dibuktikan secara akurat. Justru dari sudut psikologis mengatakan bahwa kekerasan fisik maupun psikologis yang dialami semasa anak-anak terbukti memiliki kaitan dengan terbentukanya ketertarikan sesama jenis ${ }^{5}$. Demikian dari aspek lingkungan sosial.

Albert Bandura menuliskan bahwa prilaku seseorang diperoleh dari interaksi sosial seseorang dengan orang tua, teman sebaya dan media sosial, demikian juga halnya dengan perilaku seksual. ${ }^{6}$

Oleh sebab itu Pendidikan keluarga dan lingkungan sangat berperan membuat seseorang memiliki identitas seks menjadi LGBT. Allah tidak pernah menciptakan orientasi seks dengan sesama jenis. Saat manusia pertama diciptakan didunia ini, Allah menjadikan laki-laki dan perempuan untuk melangsungkan keturunannya (Kejadian 1:28). Hanya ada dua identitas sex yang Tuhan berikan kepada manusia yaitu laki-laki dan perempuan.

Hanya mereka yang memiliki perbedaan jenis kelamin, yang dapat melangsungkan keturunan dan itulah yang Tuhan perintahkan serta diberkati. Dengan perbedaan jenis kelamin akan berfungsi untuk memenuhi syarat dalam kelahiran. Sehingga tidak boleh LGBT menyebutkan bahwa identitas mereka dapat dikatakan normal dan sesuai kehendak Pencipta. Jika kita mengatakan bahwa prilaku seks sesama jenis dipengaruhi oleh karena faktor biologi, genetik maka akan menjadi alasan yang kuat hal ini dilegalkan karena ada sesuatu pembenaran bahwa itu karena kondisi kelahiran.

${ }^{4}$ Hamer DH, Mustanski BS, DuPree MG, Nievergelt CM, Bocklandt S, Schork NJ, "A Genome-Wide Scan of Male Sexual Orientation. Human Genetics 116:272-8” (2005), dikutip dalam Andik Wijaya, Biblicomedic Perspective On LGBTIQ: A Biblical and Medical Review of Sex, Gender, and Sexuality (Kenza Publishing House, 2018), 8.

${ }^{5}$ Reports of Parental Maltreatment during Childhood in a United States Population-Based Survey of Homosexual, Bisexual, and Heterosexual Adults: Child Abuse \& Neglect 26, 2002, dikutip dalam Andik Wijaya, Biblicomedic Perspective On LGBTIQ: A Biblical and Medical Review of Sex, Gender, and Sexuality (Kenza Publishing House, 2018), 10.

${ }^{6}$ A. Dean Byrd, "Homosexuality: Innate and Immutable? What Science Can and Cannot Say," Liberty University Law Review Vol. 4, no. 3 (2010). 
Misalnya Gereja Komunitas Anugerah (GKA) di bilangan Jakarta Pusat, dikabarkan menerima keanggotaan LGBT tanpa syarat. Artinya ditak perlu melakukan sebuah perubahan perilaku terhadap mereka yang LGBT.7 Banyak Gereja-gereja mendesak $L G B T$ dapat diterima dengan legal dan termasuk mengijinkan seorang pendeta dari kalangan LGBT. Bahkan dalam surat Pastoral PGI tentang LGBT sebanyak 4 halaman dengan surat bernomor 360/PGI-XVI/2016 menyatakan sikap terhadap LGBT untuk menerima mereka. ${ }^{8}$

Jika ini terjadi maka pertumbukan LGBT dipastikan akan semakin besar seiring diterimanya prilaku seks sesama jenis oleh gereja. Dan tentu kebiasaan yang terjadi didalam masyarakat yang diterima akan mempengaruhi generasi-generasi berikutnya. Seorang LGBT selalu membenarkan tindakan mereka bahwa yang terjadi bukanlah kemauan mereka, namun jiwa sebenarnya yang sudah dirancang sejak lahir. Hal ini menimbulkan dukungan yang kuat dan dukungan itu akan membuat populasi LGBT semakin besar.

Berdasarkan wawancara yang dilakukan pada tanggal 25-27 Agustus 2021 kepada para ahli dalam bidang agama dan jabatannya di instansi sosial dan kependukukan serta saran dari sebuah jurnal yang mengangkat perlunya langkahlangkah kongkrit sebagai upaya 'penyembuhan dan pemulihan' kaum LGBT agar kembali kepada identitas seksual yang normal. ${ }^{9}$ Dalam hal ini identitas yang sesuai dengan penciptaan manusia hanya ada dua identitas sex yaitu laki-laki dan perempuan. Melihat bahwa sebuah penelitian perlu pemecahan masalah untuk mengembalikan kepada identitas yang Tuhan kehendaki bukan yang dikehendaki oleh manusia dalam hal ketertarikan sex sesama jenis maka peneliti ingin mencegah munculnya identitas tersebut sebagai bagian pertentangan dari dogma Gereja melalui dua cara yaitu pendekatan faktor keluarga dan lingkungan sosial sehingga diharapkan penelitian ini dapat bermanfaat bagi umat-umat Tuhan dapat membina untuk penguatan pertumbuhan karakter anak-anak remaja khususnya.

\footnotetext{
${ }^{7}$ Audy dan Okta Prima Putra, "7 Alasan Mengapa LGBT Diterima Gereja," https://sejuk.org/2019/07/16/7-alasan-mengapa-lgbt-diterima-gereja/ (diakses 25 Juli 2021 .

${ }^{8}$ Perspektif Biblicomedic, "Pernyataan Pastoral Pgi Tentang Lgbt" (2016).

${ }^{9}$ Roby Yansyah and Rahayu Rahayu, "Globalisasi Lesbian, Gay, Biseksual, Dan Transgender (Lgbt): Perspektif Ham Dan Agama Dalam Lingkup Hukum Di Indonesia,” Law Reform 14, no. 1 (2018): 132.
} 


\section{Metode Penelitian}

Penelitian ini menggunakan metode kualiatif yang sifatnya deskriptif dengan melakukan wawancara mendalam dari ahli yang ditentukan sebagai informan. Wawancara adalah cara mendapatkan informasi dengan bertemu langsung dengan jumlah responden yang sedikit. ${ }^{10}$ Informan yang ditentukan pada penelitian ini adalah mereka yang memiliki jabatan dan kepercayaan di masyarakat baik tokoh agama dan pemerintahan yang memiliki kemampuan dan kapasitas untuk mendeskripsikan faktor faktor yang memengaruhi penyikapan para remaja tentang fenomena LGBT di sekitar mereka dengan menggunakan pendekatan studi pustaka. ${ }^{11}$

\section{Hasil dan Pembahasan}

Keperluan Manusia terhadap Pendidikan

Pendidikan adalah bagian dari kehidupan yang tidak bisa dilepaskan dari manusia. Karena dengan pendidikan manusia dapat belajar akan kehidupan yang dijalani untuk menghadapi setiap tantangan yang terjadi. Menurut Ki Hadjar Dewantara, pendidikan adalah pedoman manusia secara menyeluruh dalam kehidupan manusia yang dimulai sejak awal sehingga dapat meghadapi pengaruh-pengaruh lingkungan, sehingga memiliki kehidupan yang baik. ${ }^{12}$

Dengan pendidikan, manusia memiliki prinsip dalam kehidupan untuk berpendirian ditengah kehidupan masyarakat yang mampu membuat seseorang tidak menyimpang secara moral dari norma-norma yang berlaku. ${ }^{13}$ Keluarga adalah Sebuah kumpulan manusia yang hidup bersama dan berdampingan dengan satu rasa untuk saling membangun, mendukung dan belajar dalam interaksi sosial. ${ }^{14}$

Sehingga Pendidikan dan keluarga adalah satu bagian yang erat yang saling melengkapi satu dengan yang untuk mencapai satu tujuan yang baik dalam kehidupan.

\footnotetext{
10 Sudaryono, Metode Penenelitian: Kuantitatif, Kualitatif, Dan Mix Method, 2nd ed. (Depok: Rajawali Press, 2019), 222.

11 Dwi Andrianta, Stimson Hutagalung, and Rolyana Ferinia, "Kontekstualisasi Ibadah Penghiburan Pada Tradisi Slametan Orang Meninggal Dalam Budaya Jawa," Visio Dei: Jurnal Teologi Kristen 2, no. 2 (2020): 244-264.

12 Ki Suratman, Tugas Kita Sebagai Pamong Taman Siswa (Yogyakarta: Majelis Luhur:, 1987), dikutip oleh Henricus Suparlan, "Filsafat Pendidikan Ki Hadjar Dewantara Dan Sumbangannya Bagi Pendidikan Indonesia," Jurnal Universitas Sarjanawiyata Tamansiswa (2016): 61.

13 Ibid, 59

${ }^{14}$ Robert M. Berns, Child, Family, School, Community Socilization and Support (United State: Thomson Corporation, 2007), 25.
} 
Melalaikan pendidikan di dalam keluarga akan membuka kejahatan-kejahatan didalam lingkungan masyarakat yang pada akhirnya akan berpengaruh didalam Gereja. Setiap orang harus benar-benar menyadari dasar dari setiap kehidupan yang berbahagia, sangat dipengarhui oleh pendidikan dalam keluarga.

Dalam berbagai tulisan, para ahli memberikan berbagai pengertian tentang pendidikan keluarga. Pendidikan keluarga adalah tempat dimana anak-anak mendapatkan pendidikan moral, kerohanian, membanguna karakter, intelektual, pendidikan sosial dan pendidikan seksual yang disesuaikan dengan usianya. ${ }^{15}$

Dalam penelitian Pamela Darby-Mullins Tamera B. Murdock menghasilkan bahwa pendidikan keluarga secara umum sangat berkontribusi dalam penerimaan identitas seksual seseorang. Peranan keluarga sangat penting dan membantu seorang anak remaja dengan sadar menghindari praktek LGBT.16

Dalam pendidikan keluarga orangtua bukan saja memberikan pendidikan seksual dengan sederhana namun membangun hubungan dengan anak.

Hubungan yang kuat akan memberikan kejujuran akan apa yang sedang dihadapi seorang anak yang mungkin dihadapi diluar dari lingkungan keluarga. Sehingga keterbukaan inilah yang akan menolong kembali orangtua untuk memberikan pendidikan yang benar dalam keluarga dalam hal menangkal penyimpangan seks $L G B T$.

\section{Lingkungan Sosial}

Lingkungan sosial dapat dimengerti secara mudah adalah lingkungan yang melingkupi kegiatan, pergaulan, percakapan, transaksi informasi dan adat budaya dari masayarakat heterogen ataupun homogen di suatu lingkungan masyarakat yang dicermati. Dalam kamus besar bahasa indonesia, sosial adalah yang berkenan dalam masyarakat. ${ }^{17}$ Menurut opini penulis bahwa lingkungan sosial yang terkecil dapat diperankan oleh lingkungan keluarga.

${ }^{15}$ Janse B. Non-Serrano, "Keluarga Sebagai Lembaga Pendidik Pertama Dan Utama: Studi Kitab Ulangan 6:1-9," Pendidikan Agama Kristen: Regula Fidei 1, no. 1 (Maret 2016): 86-90.

16 Pamela Darby-Mullins and Tamera B Murdock, "The Influence of Family Environment Factors on Self-Acceptance and Emotional Adjustment Among Gay, Lesbian, and Bisexual Adolescents," Journal of GLBT Family Studies 3, no. 1 (January 1, 2007): 75-91, https://doi.org/10.1300/J461v03n01_04.

17 Kamus Besar Bahasa Indonesia, "Sosial," https://kbbi.web.id/sosial (diakses 3 Agustus 2021 
Aneka ragam lingkungan sosial seperti telah diungkapkan diatas adalah sangat banyak bervariasi menurut anggaran dasar atau paham dari anggota yang berasosialisasi. Mulai dari yang terkecil yaitu keluarga, asosiasi umat beragama di rumah ibadah, asosiasi dari alumni perguruan tinggi, asosiasi pekerja di suatu partai politik dan berbagai asosiasi lain. Dalam hal ini penulis akan mengambil dari sosial keluarga.

Secara positif lingkungan Sosial dapat memberikan ikatan hubungan yang memiliki empati dan mempererat tali persaudaraan, terciptakan lingkungan yang damai dan saling memiliki satu dengan yang lain. Dan lingkungan social ini mencakup lingkungan didalam keluarga, sekolah dan masyarakat. ${ }^{18}$ Lingkungan keluarga misalnya berperan penting dalam hal ini bagaimana keluarga menjadi lingkungan utama untuk membangun norma-norma dan moral.

Bila keadaan lingkungan bisa membawa pengaruh atas sikap atau sebaliknya hingga terjalin internalisasi nilai, seseorang akan bisa menghalangi diri untuk bersikap bijaksana dalam menyikapi fenomena LGBT. Orang bisa meribah anggapan sekalian pola fikir yang bersimpul pada pola sikap dalam menolak ataupun mengikuti fenomena tertentu. Seseorang yang dihadapkan kepada prilaku yang baru yang menyimpang di lingkungan sosial dapat memutuskan hal itu salah sehingga dapat mengindar dari praktek yang tidak benar.

Dalam penelitian Weny Amelia, Alfitri Retno Jayenti Efendi menyimpulakn bahwa ada terdapat penemuan kuat yang berkaitan dengan lingkungan atas terjadinya penyimpangan seksual. ${ }^{19}$

Lingkungan sekolah dalam pergaulan anak murid sesungguhnya dapat menjadi konstruksi prilaku anak remaja menjadi $L G B T$. Seorang yang salah mendapatkan teman akan menjadi gerbang terpengaruhnya seseorang untuk melakukan praktek penyimpangan. Namun oleh karena ada penguatan dari lingkungan keluarga atas pendidikan dan hubungan yang baik dalam keluarga, maka segera itu dapat dihindari.

18Finsani Putri, "Peran Lingkungan Pada Kehidupan Sosial Serta Baik Buruknya," https://www.kompasiana.com/finsyani/5e00ca6a097f366ae5735742/peranlingkungan-pada-kehidupan-sosial-serta-baik-buruknya?page=2 (diakses 2 Desember 2020).

${ }^{19}$ Retno Jayenti Efendi Weny Amelia, Alfitri, “Hubungan Lingkungan Terhadap Perilaku Lgbt Di Yayasan Taratak Jiwa Hati Kota Padang," Evaluasi Kinerja Karyawan Bank Rakyat Indonesia Syariah Cabang Padang XIV, no. 02 (2020): 97-109. 
Dalam wawancara Gilbert Lumoindang kepada Veronika seorang mantan Lesbian, ia menjelaskan bahwa dia menjadi Lesbi bukan karena sesuatu dari dalam namun karena pergaulan dan kondisi:

“Saya memperayai dan saya rasakan saya kecil sebenarnya saya tahu saya sebaga anak perempuan. Tuhan maunya saya disitu. Bahkan saya umur 6 tahun saya ada si sekolah minggu dan itu sekolah memang sekolah Kristen. Jadi saya sudah mengerti pengajaran yang Tuhan mau. Namun karena situasi dan orangtua yang begitu sibuk, kurang perhatian, kurang kebersamaan dengan orang tua karena kami itu keluarga besar, jadi ada seperti diabaikan. Jadi akhirnya kita itu kebawa arus dimana situasi mencari perhatian didapatkan dari kawan."20

Dalam wawancara yang sama, pria yang sudah transgender menjadi perempuan mengakui bahwa dia tidak merasakan kedamaian, ada sukacita. Tapi roh ketakutan itu ada dalam dirinya. Dia merasa, ada satu sisi yang masih ditutupi sehingga ia membuat kebohongan ke kebohongan yang lain. Dia merasakan kelelahan atas kehidupan yang dia jalani. Ada sesuatu yang dia rasakan bahwa dia bukanlah perempuan yang sempurna." Hingga akhirnya dia bisa lepas dari belenggu transgender. Jonatan mengakui bahwa apa yang dilakukan adalah dosa, yaitu dosa perjinahan. Sebelumnya, ia berpikir apa yang dilakukannya selama ini adalah hal yang tidak salah. Namun dibalik kehidupan yang dijalaninya selama ini, ada satu waktu ia merasakan kekosongan dalam kehidupannya bahwa apa yang kita anggap kebenaran menurut pandangan kita, sebetulnya ada kekosongan, pemberontakan yang sedang kita jalani. Ada yang menyatakan dalam hati kecilnya bahwa dia tidak normal.

${ }^{20}$ Gilbert Lumoindan, "LGBT Dijauhi Atau Dikasihi?", https://www.youtube.com/watch?app=desktop\&v=theUvE_rqzQ (diakses tanggal 20 Agustus 2021). 


\section{Definisi LGBT (Lesbian, Gay, Bisexual, dan Transgender)}

LGBT merupakan singkatan dari kata Lesbian, Gay, Biseksual, dan Transgender. ${ }^{21}$ Gay adalah orientasi seks yang menyukai sesama jenis antara laki-dengan laki-laki, Lesbian adalah orientasi seks yang menyukai sesama jenis antara wanita dengan wanita. Sedangkan Bisexual memiliki dua orientasi seks. Bagi pria menyukai wanita disaat yang sama juga menyukai pria dan sebaliknya untuk wanita. Sedangkan Transgender sendiri adalah mereka yang mengganti jenis kelaminnya dari yang sebenarnya ${ }^{22}$. Lalu pengertiannya berkembang lagi menjadi LGBTIQ (Lesbian, Gay, Biseksual, Transgender, Intersex, Queer). Intersex adalah mengacu pada mereka yang jenis kelaminnya tidak didefinisikan dengan jelas karena perbedaan genetik dan Querr adalah istilah payung untuk orang yang tidak lurus ${ }^{23}$.

LGBT masuk dalam kategori penyimpangan seksual. Disebut sebagai penyimpangan seksual karena bertentangan dengan norma-norma agama dan budaya yang tidak sesuai dengan fungsinya. Jadi penyimpangan seksual adalah perilaku seks seseorang yang belawanan dengan hakikat seks yang diberikan Tuhan kepadanya dan dilakukan dengan cara-cara yang tidak wajar atau tidak nomal. ${ }^{24}$

\section{Pembentukan Perilaku}

Masalah LGBT adalah masalah perilaku atau behaivor yang pada masa sekarang sudah dianggap mengancam perkembangan psikologis dari umat beragama terutama bagi penganut paham ketimuran yang memiliki tradisi kuat dalam adat istiadat. Perilaku (Behavior) LGBT sesungguhnya nama julukan dari status prilaku seseorang, adalah hasil pengembangan dari keijinan persepsi individu menanggapi stimulus yang menguatkan dari luar (reinforcement factor) dalam mengembangan apapun bawaan dari keluarganya (predisposing factor) di suasana kemudahan yang memampukan adanya perubahan tersebut (enabling factor).

\footnotetext{
${ }^{21}$ Anisa Fauziah, Sugeng Samiyono, and Fithry Khairiyati, "Perilaku Lesbian Gay Biseksual Dan Transgender ( Lgbt) Dalam Perspektif Hak Azasi Manusia," Jurnal Surya Kencana Satu : Dinamika Masalah Hukum dan Keadilan 11, no. 2 (2020): 151.

${ }^{22}$ Yansyah and Rahayu, "Globalisasi Lesbian, Gay, Biseksual, Dan Transgender (Lgbt): Perspektif Ham Dan Agama Dalam Lingkup Hukum Di Indonesia."

${ }^{23}$ Andik Wijaya, 71.

${ }^{24}$ Dicky Surahman, "Pengaruh Penyimpangan Seksual Dalam Perilaku Dan Pola Pikir Siswa Terhadap Prestasi Belajar Pada Mata Pelajaran Pendidikan Agama Islam DI SMPN 1 Kapetakan Kabupaten Cirebon" (Institut Negeri Syekh Nurjati, 2011), 21.
} 
Perilaku tidak terbentuk dengan sendirinya. Hal itu sangat dipengaruhi oleh sitmulus yang artinya hal-hal dari luar yang memberikan pengaruh kepada terbentuknya perilaku bak itu yang baik atau buruk. Carri Noer Fida Yanik mengutip teori Preced Proced dari Lawrence Green yang mengatakan perilaku kehidupan seseorang dipengaruhi oleh Predisposing, Enabling, dan Reinforcing. ${ }^{25}$

Predisposing adalah yaitu faktor yang dimiliki oleh pihak remaja di lingkungan rumah tangga / keluarga sendiri atapun faktor demografis dan status bawaan lahir. Variabel ini dapat dipilah menurut jenis-jenis karakter bawaan lahir repsonden, jenis kelamin, usia, kondisi fisik / kesehatan kronis. Semua faktor predisposing diprediksi mampu memengaruhi behavior bila tidak terkendali.

Enabling adalah faktor dari lingkungan yang memberikan fasilitas dilakukannya tindakan oleh seseorang. Faktor ini memungkinkan terjadinya suatu prilaku baik itu benar atau salah. Dalam hal prilaku LGBT, yang membuat seseorang memungkinkan dapat masuk kedalam prilaku seksual menyimpang ini adalah lewat media sosial, tempat berkumpulnya kaum $L G B T$, dan prasarana dimana komunitas ini bisa muncul. Reinforcing adalah, adalah faktor pendorong atau penguat motivasi individu melakukan motivasinya seperti dukungan keuangan, fasilitas yang diperoleh dari luar rumah, paksaan dari kelompok / organisasi massa, popularitas yang dipopulerkan oleh idola, upah atau bonus yang dijanjikan oleh kelompok bila sukse dalam sesuatu tindakan tertentu.

Dalam jurnal yang ditulis Dhea Marthilda dan kawan-kawan mengutip penyataan Tan yang mengatakan bahwa penyebab seorang menjadi lesbian adalah dipengaruhi faktor keadaan keluarga, adanya hubungan antara orangtua yang sering ribut, dengan anak-anak yang membawa hubungan tidak harmonis, juga pengalaman mendapatkan pelecehan seksual pada masa anak-anak serta pengaruh lingkungan itu sendiri"26

${ }^{25}$ Carri Noer Fida Yanik, "Perilaku Petugas Kebersihan Dalam Pengelolaan Limbah Padat Berdasarkan Standard Operating Procedure (Sop) Di Rumah Sakit X Jember,” 2018, 29.

${ }^{26}$ Rulita Hendriyani Dhea Marthilda, Moh Iqbal Mabruri, "Faktor-Faktor Pemilihan Orientasi Seksual (Studi Kasus Pada Lesbian) Dhea," Journal Unnes 1, no. 1 (2014): 19. 


\section{Orientasi Seksual Dikaitkan Dengan Pendidikan Keluarga Dan Lingkungan Sosial}

Maraknya orientasi seks $L G B T$, sering sekali keberadaannya mengejutkan kita sebab mereka adalah mereka yang dianggap sebagai orang-orang yang dipercaya ditengah masyarakat sosial bahkan ditengah lingkungan gereja.

Dalam wawancara mendalam yang dilakukan kepada 4 orang ahli dari berbagai bidang pekerjaan menyampaikan bahwa LGBT terbentuk bukan sejak dari kandungan. Artinya itu bukan kodrat yang diturunkan oleh yang Mahakuasa melainkan dipengaruhi dari pendidikan keluarga dan lingkungan sosial yang kurang baik yang menyebabkan terjadinya penyimpangan seksual.

Untuk sebuah kasus, peneliti mendapatkan informasi dari beberapa orang terdekat bahwa seorang Homoseksual menikah dan diberkati dalam gereja tanpa diketahui oleh Gereja status yang bersangkutan bahkan oleh pasangannya sendiri. Pria ini terlahir sebagai Heteroseksual namun lingkungan tempat berolahraga (gym) membuat pengaruh perubahan perilaku seksual didalam dirinya. Sementara itu, seorang anak pria yang memiliki perilaku seperti wanita dianggap oleh orangtua sebagai hal yang wajar. Umumnya pria berteman dengan pria, namun anak tersebut lebih membuka diri berteman dengan wanita. Tidak jarang hal yang seperti ini dapat menjadikan seseorang menjadi Lesbian atau Transgender.

Beberapa orangtua justru memberikan kemungkinan terbentukanya sebuah perilaku LGBT terhadap anak. Misalnya, keinginan orangtua mendapatkan anak laki-laki ternyata yang lahir perempuan. Lalu sejak kecil diberikan pakaian laki-laki akhirnya membentuk perilaku anak tersebut bahwa dia merasa laki-laki. Demikian sebaliknya.

Seperti yang dijelaskan oleh Kepala Perwakilan Badan Kependudukan dan Keluarga Berencana Nasional (BKKN) Provinsi Kepri bawah keluarga adalah untuk mencegah orientasi seks anak yang salah. Sebab keluarga adalah dasar pendidikan bagi pertumbuhan anak-anak. Mungkin ada anak laki-laki terlahir lebih dominan maskulin namun orangtua harus berperan aktif dalam pendidikan keluarga bahwa dia adalah seorang laki-laki. Keluarga harus lebih dominan untuk menolak dengan berusaha bukan menekan. Tetapi justru yang terjadi ada anak laki-laki diberikan pakaian perempuan. Atau mungkin perilaku yang didapat anak dari Televisi, orangtua menganggap sesuatu yang wajar sebagai permainan.

Belum lagi adanya pengaruh reinforcing yaitu adanya penguatan dari masyarakat karena kebebasan ditengah lingkungan sosial dimana warga tidak menegor praktek 
$L G B T$ yang terlihat jelas di lingkungannya. Hal inilah yang membuat $L G B T$ semakin berkembang. ${ }^{27}$

Jika keluarga adalah kunci utama bagi karakter anak maka keluarga harus menjalankan fungsi keluarga antara lain:

1. Fungsi keagamaan: memberi teladan yang baik dalam rohani dan perilaku

2. Fungsi reproduksi: perencanaan anak, jarak kelahiran, dan kesehatan reproduksi

3. Fungsi sosial budaya: jadilah teladan dalam bertutur, dan bertindak baik bagi anak

4. Fungsi sosialiasi dan pendidikan: Bersosialisasi dengan sopan dan berpendidikan

5. Fungsi ekonomi: bertanggung jawab memenuhi kebutuhan Rumah tangga

6. Fungsi perlindungan: tumbuhkan nyaman dan aman dalam keluarga

7. Fungsi cinta kasih: memberi cinta kasih pada anak dengan efektif

8. Fungsi pembinaan lingkungan: menjaga keharmonisan keluarga dan lingkungan

Jika fungsi ini dijalankan maka akan mencegah terbentuknya sebuah perilaku seks LGBT yang menyimpang ditengah masyarakat.

Senada yang disampaikan Akhmad Yani KASI Rehabilitasi Dan Korban Perdagangan Orang Dinas Sosial Dan Pemberdayaan Masyarakat Kota Batam. Seorang LGBT sebenarnya didalam dirinya tidak ada prilaku tersebut:

faktor seorang menjadi $L G B T$ adalah akibat kurang kontrolnya dari pihak pendidikan dalam keluarga. Kurang adanya bimbingan ataupun kurang perhatian dalam keluarga sehingga mereka terpengaruh oleh lingkungan ikut-ikutan teman-temannya tadi. Dan ada komunitas. Dan mungkin karena ini semata-mata sumber mata pencaharian yang mudah diperoleh mereka terpengaruh. ${ }^{28}$

Didalam pendidikan keluarga dapat mengajarkan pendidikan seks kepada anak-anak secara sederhana yang bersifat kudus untuk menunjukan penempatan kasih yang benar. ${ }^{29}$ Keberhasilan pendidikan Kristen merupakan teladan baik yang diturunkan orangtua kepada anak-anak mereka. ${ }^{30}$ Seorang pria harus dapat melakukan peranan sebagai seorang nabi dan imam bagi istri dan anak-anaknya dengan mengajarkan Firman Tuhan dan berdoa bagi keluarganya.

27 Wawancara dengan Mediheryanto pada tanggal 08 September 2021.

28 Wawancara dengan Akhmad Yani pada tanggal 26 Agustus 2021.

${ }^{29}$ Bakhoh Jatmiko, "Hakekat Seksualitas Manusia : Perspektif Gereja Kristen Nazarene Di Abad 21 Terhadap Praktek LGBT,” Sanctum Domine: Jurnal Teologi 4, no. 1 (2019): 29-39.

${ }^{30}$ Aby Gayel, Stimson Hutagalung, and Rolyana Ferinia, "Tantangan Mendidik Anak-Anak Pendeta Di Gereja Masehi Advent Hari Ketujuh (GMAHK) DKI Jakarta Melalui Penerapan Disiplin Dan Keteladanan," EDULEAD: Journal of Christian Education and Leadership 2, no. 1 (2021): 102-119. 
Pendidikan keluarga dan lingkungan sosial sangat berperan untuk membentuk perilaku seorang anak seperti pandangan dari ketua Badan Kerjasama Antar Gereja (BKKAG) Kota Batam, yang kesehariannya adalah seorang praktisi kesehatan dan Gembala Gereja, Ia melihat bahwa seorang LGBT keberadaan yang ingin dihargai dan motivasi mereka ingin mendapat kasih sayang yang mereka tidak dapat dalam keluarga. Peran orangtua sangat berperan untuk memberikan pendidikan bagi seorang. Dan pendidikan itu dimulai sejak dini. Lalu adanya tekanan yang didapat dari lingkungan keluarga dan sosial sehingga ia mencari sendiri yang akhirnya membawa dia kepada situasi terjebak dalam praktek LGBT. Ada perasaan nyaman didapatkan dari seseorang yang memiliki same sex attraction saat di melakukan hubungan dengan orang tersebut. Dia menambahkan bahwa menurut dunia kedokteran tidak ada gen LGBT atau kelainan genetik namun sesungguhnya gangguan prilaku. ${ }^{31}$

Demikian dengan Erlingson Pakpahan, Ketua aras Gereja Masehi Advent Hari Ketujuh (GMAHK) Provinsi Kepulauan Riau berpendapat bahwa adanya kecendrungan seseorang menjadi seorang LGBT sangat dipengaruhi dari pendidikan keluarga lewat kurangnya perhatian dah hubungan yang baik dari orangtua kepada anak-anak dan juga pengaruh dari komunitas atau kelompok yang memberikan fasilitas kenyamanan yang membuat anak-anak remaja terjebak dengan prilaku seksual LGBT. Ditambah kondisi masyarakat yang tidak terlalu mempedulikan membuat LGBT ini menjamur di lingkungan kos-kosan. ${ }^{32}$

Jika tanggung jawab orangtua benar-benar dijalankan maka akan menghasilkan keluarga, masyarakat dan gereja yang sehat. ${ }^{33}$ Pada saat seorang ayah memperankan kasih kepada istrinya, maka seorang anak wanita dapat memandang seorang pria dengan rasa hormat dan sebaliknya. Keluarga adalah penguatan karakter seorang anak saat mereka keluar ke lingkungan luar. Itu adalah kunci kepada keberhasilan seseorang dalam kesuksesan dan menghadapi tantangan pengaruh buruk kedalam dirinya. ${ }^{34}$ Pendidikan keluarga sangat berperan terhadap pembentukan karakter seorang anak remaja untuk menolak perilaku buruk. Itu sebabnya kita harus mengajarkan secara

\footnotetext{
31 Wawancara dengan Surya Wijaya pada tanggal 26 Agustus 2021.

32 Wawancara dengan Erlingson Pakpahan pada tanggal 30 Agustus 2021.

${ }^{33}$ S. Hutagalung, "Tiga Dimensi Dasar Relasi Manusia Dalam Kehidupan Sosial," Jurnal Koinonia 10, no. 2 (2015): 81-91.

34 Jito Subianto, "Peran Keluarga, Sekolah, Dan Masyarakat Dalam Pembentukan Karakter Berkualitas," Edukasia : Jurnal Penelitian Pendidikan Islam 8, no. 2 (2013): 331-354.
} 
terus menerus sejak kecil dimanapun mereka berada sehingga akan membetuk kebiasaan dan tabiat yang baik (Ulangan 6:6-7).

Dosa tidak terjadi tiba-tiba, itu dibentuk dari salah satu yang berperan penting dalam lingkungan sosial. Seorang pria harus menetapkan batas-batasan sosial dengan 'tegas' karena hubungan sosial adalah media utama terjadinya dosa seksual. Lingkungan sosial tidak hanya dilihat dari tempat tapi pengaruh lingkungan media sosial memberikan sumbangsi besar terjadinya pembentukan penyimpangan seks yang salah. ${ }^{35}$

Perilaku yang salah dapat terbentuk didalam diri seseorang jika pergaulan yang tidak benar dilakukan. Bergaul dengan orang yang tidak tepat pada lingkungan yang salah membuat anak-anak remaja dapat membentuk identitas Sex LGBT. Sebagai seorang setia kepada Tuhan, Daud jatuh kedalam dosa pada saat melihat istri uria sedang mandi. Ini adalah pembentukan perilaku dari Enabling dimana seseorang adanya sebuah peluang dosa.

Setiap saat kesempatan jatuh kedalam dosa terbuka bagi setiap orang. Itu sebabnya kita harus membuat sikap kepada siapa kita bergaul. Pergaulan ditengah lingkungan yang baik akan mempengaruhi karakter kita dan pergaulan ditengah-tengah lingkungan yang jahat akan memberikan pengaruh yang jahat bagi anak-anak remaja. (Amsal 13:20).

\section{Kesimpulan}

Gereja memiliki sudut pandang yang berbeda terhadap identitas seks LGBT yang mengijinkan sesama jenis menyukai satu dengan yang lain yang menimbulkan persoalan ditengah-tengah Gereja. Pribadi LGBT bukan untuk ditolak dan diasingkan dalam Gereja namun Identitas Seks LGBT yang bertentangan tersebut perlu dipulihkan atau disembuhkan, khususnya dicegah. Perlu pencegahan secara terpadu dari setiap lapisan masyarakat pemerintah, tokoh adat dalam peranannya sebagai lingkungan sosial dalam peranannya untuk merubah dan menyadarkan mereka dari dari terbentuknya identitas LGBT dan Khususnya keluarga-keluarga dari sejak dini untuk memberikan pendampingan dalam pendidikan dan kasih sayang dalam penguatan pribadi anak-anak

${ }^{35}$ Andik Wijaya, Equipping Men to Fight for : Sexual Holiness (Kenza Publising House, 2015), 162164. 
remaja untuk terhindar dari terbentuknya identitas $L G B T$. Perilaku seks seseorang yang salah berdasarkan ajaran Firman Tuhan sangat dipengaruhi dari stimulus yang salah baik lemahnya perhatian dan pendidikan dalam keluarga dan buruknya lingkungan sosial akhirnya memberikan penguatan terhadap prilaku yang salah. Oleh sebab itu menempatkan diri pada lingkungan yang benar dan perhatian keluarga, akan menjaga iman seseorang dari perbuatan seks dan pembentukan perilaku seks yang benar.

\section{Referensi}

Andik Wijaya. Equipping Men to Fight for : Sexual Holiness. Kenza Publising House, 2015.

Andrianta, Dwi, Stimson Hutagalung, and Rolyana Ferinia. "Kontekstualisasi Ibadah Penghiburan Pada Tradisi Slametan Orang Meninggal Dalam Budaya Jawa." Visio Dei: Jurnal Teologi Kristen 2, no. 2 (2020): 244-264.

Aziz, Safrudin. Pendidikan Sex Perspektif Terapi Sufistik Bagi LGBT. Kendal: Penerbit Ernest, 2017.

Berns, Robert M. Child, Family, School, Community Socilization and Support. United State: Thomson Corporation, 2007.

Biblicomedic, Perspektif. "Pernyataan Pastoral Pgi Tentang Lgbt” (2016).

Byrd, A. Dean. "Homosexuality: Innate and Immutable? What Science Can and Cannot Say." Liberty University Law Review Vol. 4, no. 3 (2010).

Darby-Mullins, Pamela, and Tamera B Murdock. "The Influence of Family Environment Factors on Self-Acceptance and Emotional Adjustment Among Gay, Lesbian, and Bisexual Adolescents." Journal of GLBT Family Studies 3, no. 1 (January 1, 2007): 7591. https://doi.org/10.1300/J461v03n01_04.

Dhea Marthilda, Moh Iqbal Mabruri, Rulita Hendriyani. "Faktor-Faktor Pemilihan Orientasi Seksual (Studi Kasus Pada Lesbian) Dhea." Journal Unnes 1, no. 1 (2014): 19.

Dicky Surahman. "Pengaruh Penyimpangan Seksual Dalam Perilaku Dan Pola Pikir Siswa Terhadap Prestasi Belajar Pada Mata Pelajaran Pendidikan Agama Islam DI SMPN 1 Kapetakan Kabupaten Cirebon." Institut Negeri Syekh Nurjati, 2011.

Fauziah, Anisa, Sugeng Samiyono, and Fithry Khairiyati. "Perilaku Lesbian Gay Biseksual Dan Transgender ( Lgbt) Dalam Perspektif Hak Azasi Manusia." Jurnal Surya Kencana Satu : Dinamika Masalah Hukum dan Keadilan 11, no. 2 (2020): 151.

Gayel, Aby, Stimson Hutagalung, and Rolyana Ferinia. "Tantangan Mendidik Anak-Anak Pendeta Di Gereja Masehi Advent Hari Ketujuh (GMAHK) DKI Jakarta Melalui Penerapan Disiplin Dan Keteladanan." EDULEAD: Journal of Christian Education and Leadership 2, no. 1 (2021): 102-119.

Hutagalung, S. “Tiga Dimensi Dasar Relasi Manusia Dalam Kehidupan Sosial.” Jurnal Koinonia 10, no. 2 (2015): 81-91.

Ikhsan, Muhammad. “Modus Komunitas LGBT Di Batam Yang Mencengangkan” (n.d.). 
https://www.batamnews.co.id/berita-39230-modus-komunitas-lgbt-di-batamyang-mencengangkan.html.

Jatmiko, Bakhoh. "Hakekat Seksualitas Manusia : Perspektif Gereja Kristen Nazarene Di Abad 21 Terhadap Praktek LGBT.” Sanctum Domine: Jurnal Teologi 4, no. 1 (2019): 29-39.

Kemenkes. "Kemenkes RI, Estimasi Jumlah Populasi Kunci Terdampak HIV Tahun 2012" (2014).

Lumoindan, Gilbert. “LGBT Dijauhi Atau Dikasihi?” Indonesia, 2019.

https://www.youtube.com/watch?app=desktop\&v=theUvE_rqzQ.

Mediheryanto. "Wawancara Oleh Penulis," n.d.

Mustanski BS, DuPree MG, Nievergelt CM, Bocklandt S, Schork NJ, Hamer DH. “A Genome-Wide Scan of Male Sexual Orientation. Human Genetics 116:272-8” (2005).

Newswire. "FENOMENA LGBT: Sekitar 3 Ribu Pelajar Di Batam Diduga Gay.” Batam, February 12, 2016.

https://kabar24.bisnis.com/read/20160212/78/518490/fenomena-lgbt-sekitar-3ribu-pelajar-di-batam-diduga-gay.

Nichol, F.D. "Seventh-Day Adventist Bible Commentary." Review and Herald Publishing Association, 1978. https://archive.org/details/SdaBibleCommentary1980/SdaBc-6 \%2846\%29 1 Corinthians/page/n169/mode/2up.

Non-Serrano, Janse B. "Keluarga Sebagai Lembaga Pendidik Pertama Dan Utama: Studi Kitab Ulangan 6:1-9." Pendidikan Agama Kristen: Regula Fidei 1, no. 1 (2016): 8690 .

Pakpahan, Erlingson. “Wawancara Oleh Penulis,” n.d.

Putra, Audy dan Okta Prima. "7 Alasan Mengapa LGBT Diterima Gereja." https://sejuk.org/2019/07/16/7-alasan-mengapa-lgbt-diterima-gereja/.

Putri, Finsani. “Peran Lingkungan Pada Kehidupan Sosial Serta Baik Buruknya,” 2020. https://www.kompasiana.com/finsyani/5e00ca6a097f366ae5735742/peranlingkungan-pada-kehidupan-sosial-serta-baik-buruknya?page=2 .

Sagala, Soulement Reuel Jenson dan Rudolf W. "Pemahaman Anggota Gereja Masehi Advent Jemaat Morion, Sabah, Malaysia Tentang Penerimaan Keanggotaa Yang Sudah Menukar Jenis Kelaminnya Berdasarkan 1 Korintus 6:9b Dan 10." Paper Knowledge. Toward a Media History of Documents (2014): 63-84.

Salim, Ali. "Siapakah Yang Dimaksud Dengan Banci Dan Orang Pemburit Dalam 1 Korintus 6:9-10?” (2016): 9-10.

Subianto, Jito. "Peran Keluarga, Sekolah, Dan Masyarakat Dalam Pembentukan Karakter Berkualitas.” Edukasia : Jurnal Penelitian Pendidikan Islam 8, no. 2 (2013): 331-354.

Sudaryono. Metode Penenelitian: Kuantitatif, Kualitatif, Dan Mix Method. 2nd ed. Depok: Rajawali Press, 2019. 
Suparlan, Henricus. "Filsafat Pendidikan Ki Hadjar Dewantara Dan Sumbangannya Bagi Pendidikan Indonesia.” Jurnal Universitas Sarjanawiyata Tamansiswa (2016): 61. http//.www.researchgate.net//publication/307523746.

Verdianto, Yohanes. "Hermeneutika Alkitab Dalam Sejarah : Prinsip Penafsiran Alkitab Dari Masa Ke Masa Metode Penelitian Dokumen . Dengan Metode Deskripsi Analitis , Yaitu Berusaha Menguraikan Berkenaan Dengan." Mitra Sriwijaya: Jurnal Teologi dan Pendidikan Kristen 1 (2020): 45-57.

Weny Amelia, Alfitri, Retno Jayenti Efendi. "Hubungan Lingkungan Terhadap Perilaku Lgbt Di Yayasan Taratak Jiwa Hati Kota Padang." Evaluasi Kinerja Karyawan Bank Rakyat Indonesia Syariah Cabang Padang XIV, no. 02 (2020): 97-109.

Wijaya, Surya. "Wawancara Oleh Penulis," n.d.

Yani, Akhmad. "Wawancara Oleh Penulis,” 2021.

Yanik, carri noer fida. "Perilaku Petugas Kebersihan Dalam Pengelolaan Limbah Padat Berdasarkan Standard Operating Procedure (Sop) Di Rumah Sakit X Jember," 2018.

Yansyah, Roby, and Rahayu Rahayu. "Globalisasi Lesbian, Gay, Biseksual, Dan Transgender (Lgbt): Perspektif Ham Dan Agama Dalam Lingkup Hukum Di Indonesia." Law Reform 14, no. 1 (2018): 132.

Reports of Parental Maltreatment during Childhood in a United States Population-Based Survey of Homosexual, Bisexual, and Heterosexual Adults: Child Abuse \& Neglect 26, 2002. 